\title{
INSOLVENCY PREDICTION IN THE PORTUGUESE CONSTRUCTION INDUSTRY
}

Elisabete S. VIEIRA* Carlos PINHO** Carla CORREIA ${ }^{* * *}$

\begin{abstract}
This study tries to determine the firms' specific variables considered determinant to predict the probability of insolvency of Portuguese companies in the construction industry, considering a sample of 150 insolvent firms and 150 operating companies. We consider a set of economic and financial ratios to analyze the insolvency prediction and apply the linear probability model, as well as the Logit and Probit models. The results show that the main ratio to predict the insolvency was the cash-flow to total assets ratio, suggesting that the higher the cash-flow to total assets ratio value, the lower the probability of insolvency. The results can be used by policy makers to minimize the spill over effect of construction crisis to the economy.
\end{abstract}

Keywords: Bankruptcy, insolvency prediction, financial ratios

\section{PORTEKİZ İNŞAAT SEKTÖRÜNDE IFLAS BEKLENTİSI}

\section{$\ddot{O}_{z e t}$}

Bu çalışma, 150 iflas etmiş ve 150 halihazırda faaliyet gösteren şirketi inceleyerek, inşaat sektöründe bulunan Portekizli şirketlerin iflas olasillğ tahmininde belirleyici olduğu düşünülen, firmalara özgü değişkenleri belirlemeye çalışmaktadır. Makalede, iflas tahmini analiz etmek ve Logit ve Probit modellerinin yanı sıra doğrusal olasılık modeli uygulamak için, bir dizi ekonomik ve finansal oran kullanılmaktadır. Sonuçlar, iflas tahmini için en önemli oranın, nakit akışının toplam aktiflere oranı arttıkça iflas olasılığının düştügüünü belirten, nakit akışının toplam aktiflere oranı olduğunu göstermektedir. Inş̧aat krizinin ekonomiye yayılma etkisini en aza indirmek için sonuçlar politika yapıcılar tarafindan kullanılabilir.

Anahtar Kelimeler: Iflas, iflas tahmini, finansal oranlar

\footnotetext{
* Coordinator Prof. Dr., GOVCOPP Unit Research, ISCA - University of Aveiro, e-mail: elisabete.vieira@ua.pt

** Assoc. Prof. Dr., GOVCOPP Unit Research, DEGEI - University of Aveiro, e-mail: cpinho@ua.pt

${ }^{* * *}$ MA, DEGEI - University of Aveiro, e-mail: carlacorreia41@ua.pt
} 


\section{Introduction}

Since Beaver (1966), Altman (1968) and Blum (1974) presented their pioneering studies on bankruptcy prediction that relied mainly in financial ratios, a vast literature has emerged applying several performance analyses of financial ratios to predict the bankrupt probability in the coming years. Despite the increasing methodological sophistication, the financial ratios' selection to analyze this phenomenon remains as relevant as in previous decades. In fact, Voulgaris, Doumpos and Zopounidis (2000) continue to share the opinion that financial ratios are unbiased quantitative representations of the firms' context.

The European prevailing financial crisis has increased the relevance of financial insolvency prediction models. Additionally, there are an increasing number of bankrupt companies recorded in recent years in Portugal, which reinforces their relevance.

In this context, we intend to analyze some models based on economic and financial indicators that can predict future situations of insolvency, within five years prior to insolvency, in the Portuguese construction industry, which is one of the most fragile sectors in what concerns the economic environment, and, consequently, is facing extreme difficulties nowadays.

This study contributes to the empirical evidence for business failure prediction models in construction companies and selects the best model that helps understanding which are the main ratios to study the insolvency.

The remainder of this paper is organized as follows. Section 2 reviews the related literature. Section 3 describes the methodology and data. Section 4 presents the empirical results. Finally, section 5 concludes the paper.

\section{Literature Review}

The first technique to be developed on financial failure prediction was based on a univariate model analysis. This type of analysis consists on a model in which the dependent variable is explained by a single independent variable. Thus, each indicator was studied separately. For instance, the model explores the ratios that can explain the probability of a firm to become insolvent.

In this context, the first known study on the analysis of financial ratios in predicting insolvencies is assigned to Beaver (1966), who presented his univariate analysis in predicting the failure of companies in the United States of America. The results show that the financial ratios could be useful to predict failure at least five years before the bankruptcy. Beaver's study was based in 79 insolvent companies and 79 healthy companies, in 38 different industries between 1954 and 1964. At first, the author considered 30 financial ratios and ended up by selecting 6 of them. 
Globally, all ratios were able to predict insolvency, however, not all had the same predictive capacity. This model was criticized because an individual ratio cannot entail sufficient information to describe the solvency of a firm.

The multiple discriminant analysis (MDA) is a multivariate statistical method consisting in the determination of a linear combination of discriminating variables, in order to statistically distinguish two groups previously defined. The dependent variable is qualitative and the discriminant features are firms' specific variables, such as financial ratios. Based on the discriminant function, the predictive capability of company insolvency can be tested.

The first MDA study was published by Altman (1968), which becomes the wellknown Z-score model. Altman used this analysis to develop a bankruptcy predictive model for productive companies, accounting for 5 discriminating factors. The study focused on 33 insolvent and 33 healthy companies between 1946 and 1965, covering ratios considered important for the financial stability of companies, such as liquidity, solvency, profitability and indebtedness. The discriminant function seems to show that financial distress could be anticipated one year prior to insolvency with accuracy for $94 \%$ of insolvent companies and $97 \%$ of healthy firms. However, the model lost ability to accurately forecast from the first to the fifth year prior to bankruptcy, from $95 \%$ to $36 \%$.

Some years later, Altman, Haldeman and Narayanan (1977) improved the original model, bringing up a new model, denominated by ZETA. In this empirical study, the authors analysed a sample of manufacturing firms and retailers, of which 53 were insolvent and 58 were healthy, for the period between 1965 and 1972. The discriminant function ZETA included 7 variables: Return on assets (EBIT / Total assets), stability of profitability, debt, cumulative profitability, liquidity, capitalization and size. This kind of model presents some restrictions as MDA assumes that the ratios are multivariate normally distributed. Further, linear discriminant analysis is more appropriate when the covariance across the variables is equal for the groups of failed and operating firms. Nevertheless, several authors used this model, such as Edmister (1972) and Agarwal and Taffler (2008).

Other studies have considered conditional probability models, such as the logit and Probit models. The Logit model uses conditional probability and is obtained from a logistic regression. This model is a statistical technique in which the dependent variable is qualitative, assuming two possible values, and can be interpreted as the probability that a particular event occurs (in this case, the particular event is the bankruptcy).

Given that the discriminant analysis model entails vulnerability, Ohlson (1980) presented a logistic regression model, which assumes a non-linear estimation. Ohlson's study was based on information collected in the period between 1970 and 
1976, in the industrial domain, with a sample of 105 insolvent companies and 2,058 healthy companies, which resulted in an unbalanced sample. The author used 9 explanatory variables and estimated three Logit models in cross-section data. The results showed 4 significant factors, affecting the likelihood of bankruptcy: company size, financial structure, and several performance and liquidity measures. Ohlson concluded that the predictive power of this model depend on the timing at which the company's financial information was obtained.

Regarding the Probit model, it derives from the cumulative function of a normal distribution and is similar to the Logit model. The two models have the same fundamental, differing only in the distribution. Zmijewski (1984) used a sample of 40 insolvent companies and 800 operating companies, analysing the period between 1972 and 1978. The author concluded that this technique did not provide qualitative results different from the results provided by random sampling techniques.

Some authors compare these models. Laitinen and Kankaanpää (1999) stated that the prediction accuracy depends on the model applied and Ugurlu and Aksoy (2006) concluded that the logistic regression produced better results than the discriminant analysis model.

Correa, Acosta and González (2003) analyzed a SME sample from Santa Cruz of Tenerife, concluding that the variables with greater explanatory capacity for bankruptcy diagnostic are the indebtedness, the economic yield and solvency indicators.

There are some empirical studies conducted in the Portuguese market.

Leal and Machado-Santos (2007) explored the bankruptcy phenomenon in the Portuguese textile industry, using a sample of 52 companies for the period 1996 to 2002. They concluded that financial distress could be anticipated with an accuracy of $97 \%, 85 \%$ and $76.5 \%$, respectively for one, two and three years before bankruptcy. In addition, they concluded that while the discriminant model separates the healthy firms from those that have financial problems, the Logit model allows estimating the probability of the company becoming insolvent.

Barros (2008) forecasted the bankruptcy of small and medium size Portuguese companies, based on a sample of 336 operating and 336 insolvent companies. Employing the Logit and the Probit models, he verified that the Z-score model was not appropriate for the sample. The results showed that the ratios with greater predictive power of bankruptcy were the profitability and the financial ratios, which measure the company's ability to meet its financial commitments.

Lacerda and Moro (2008) analyzed the companies' behavior, according to its payment obligations. Testing 47 ratios containing information on earnings, leverage, cost structure, activity, size and no accounting characteristics, they 
concluded that the support vector machine model outperformed the Logit model and the discriminant analysis.

Ribeiro (2011) tried to anticipate the failure tax firms in the wood furniture industry, using the multivariate discriminant analysis and the Logit model. Their results showed a positive relationship between debt and fiscal failure and a negative relationship between fiscal solvency and short-term failure.

\section{Methodology and Data}

\subsection{Methodology}

As this study intends to analyze the relationship between insolvency and economic and financial variables, we consider conditional probabilistic models, where the dependent variable is a dummy, which assumes the value of one if the firm is an insolvent firm, and zero otherwise (if it is an operating firm). This categorization is complete given that each company belongs to one group or to the other.

Three different approaches of analysis were considered: The linear probabilistic model (LPM), the Logit and the Probit model. The LPM is estimated by the ordinary least squares method (OLS) and the other two models are estimated by the maximum likelihood estimation (MLE).

The LPM presents some disadvantages, such as the fact that it does not guarantee the probability of a firm becoming insolvent restricted to $(0,1)$. The alternatives to LPM are the Logit and Probit models, which restrain the function to $(0,1)$. Probit assumes the normal standard distribution function and Logit assumes the logistic distribution. These models are suitable for modelling events in terms of probability and rating of one or two outputs and to assess the statistical significance of the explanatory variables of the model, capturing the heterogeneity of individual companies.

The McFadden's (1974) R-squared test may be interpreted as a measure of quality adjustment in the logistic regression. Wooldridge (2009) stated that this test is similar to the R-square in the OLS regression.

\subsection{Variables}

We start by selecting 8 variables as predictors of financial insolvency, based on previous studies. We consider these ratios preferred relative to others as they were considered determinant for insolvency prediction in earlier evidence (e.g., Beaver, 1966; Altman, 1968; Ohlson, 1980; Zmijewski, 1984).

The first ratio was considered relevant in the studies of Beaver (1966) and Zavgren (1985), and is defined as the Cash flow to total assets (CFA). The CFA 
ratio measures how successfully a company is in its capability to generate cash from its resources, and it is calculated as follows:

$$
\text { Cash flow to total assets ratio }=\frac{\text { Cash flow }}{\text { Total assets }}
$$

The debt ratio (Debt) indicates the level of indebtedness of a company. This ratio measures the level of borrowed funds used to finance the company, assessing the company's level of dependence. The greater the ratio, the higher the risk to the firm as a whole. This ratio was used by several authors, such as Beaver (1966), Ohlson (1980) and Frydman, Altman and Kao (1985), and is computed as follows:

$$
\text { Debt ratio }=\frac{\text { Total liabilities }}{\text { Total assets }}
$$

To evaluate the adequacy of the firm's cash resources relative to its obligations in order to verify the ability of debt repayment in the short term, we consider the current ratio (CR). This ratio was used by Beaver (1966) and Altman, Haldeman and Narayanan (1977):

$$
\text { Current ratio }=\frac{\text { Current assets }}{\text { Current liabilities }}
$$

The return on assets (ROA) measures the operating efficiency of the firm, or the ability to generate net income with the firms' assets. Ohlson (1980) tested the discriminant ability of this ratio:

$$
\text { Return on assets }=\frac{\text { Net income }}{\text { Total assets }}
$$

The asset turnover ratio (ATR) measures a company's investment efficiency by aggregating the joint impact of short and long-term assets. A higher asset turnover ratio suggests that the company is working very close to the limit of its capacity (Altman, 1968). It is determined by the equation:

$$
\text { Asset turnover ratio }=\frac{\text { Sales }}{\text { Total assets }}
$$

Following Altman (1968), we consider the working capital ratio (WCR), given that working capital is the excess of current assets to cover short-term debts. This ratio indicates the security margin when the lenders claim the reimbursement of the debts, and its value is given by:

$$
\text { Working capital ratio }=\frac{\text { Capital ratio }}{\text { Total assets }}
$$


The net sales margin ratio (NSM) measures the contribution of sales in generating net income. The higher the ratio value, the more its earnings power is enhanced. This ratio is derived from the net margin achieved by the company after deducting all charges:

$$
\text { Net sales margin }=\frac{\text { Net income }}{\text { Sales }}
$$

Finally, the return on equity (ROE) indicates how well a company generates net income from its equity, and reflects the return to common shareholders. This ratio was used, for example, by Zmijewski (1984):

$$
\text { Return on equity }=\frac{\text { Net income }}{\text { Equity }}
$$

These ratios analyses the firm's debt levels, the liquidity, the profitability and the business efficiency.

It is expected a positive sign to the Debt ratio, since the higher the debt, the higher the probability of a firm becoming insolvent. Regarding the profitability, the liquidity and the activity ratios, it is expected a negative sign, since the higher the ratios, the lower the probability of companies coming into economic and financial difficulties situations. The greater the ability to generate results (profitability), to pay the short-term debt on time (liquidity) and the business efficiency in generating sales (turnover), the less likely the company becomes insolvent.

Thus, we can hypothesize that the debt ratio is positively related to the probability of a firm becoming insolvent and that the cash-flow/total assets, the current asset/current liabilities, the net income/total assets, the sales/total assets, the working capital/total assets, the net income/sales and the net income/equity are negatively related to the firms' insolvency probability.

Our econometric model is based on a cross-section analysis and is given by the following expression:

$$
S_{i t_{i}}=\beta_{0}+\beta_{1} C F A+\beta_{2} D e b t+\beta_{3} C R+\beta_{4} R O A+\beta_{5} A T R++\beta_{6} W C R+\beta_{7} N S M+\beta_{8} R O E+u_{i}
$$

where:

$\begin{array}{rll}\text { Sit }_{i} & = & 1 \text { if the company } i \text { is insolvent and } 0 \text { otherwise; } \\ C F A & = & \text { Cash-flow/Total assets; } \\ \text { Debt } & = & \text { Liabilities/Total assets; } \\ C R & = & \text { Current asset/Current liabilities; } \\ R O A & = & \text { Net income/Total assets; } \\ A T R & = & \text { Sales/Total assets; } \\ W C R & = & \text { Working capital/Total assets; }\end{array}$




$\begin{array}{rll}N S M & = & \text { Net income/Sales; } \\ R O E & = & \text { Net income/Equity; } \\ u_{i} & = & \text { Error term. }\end{array}$

Because we want to study several years prior to the insolvency date, crossfunction models were run for each different year.

\subsection{Data}

Before deciding which industry to consider in the study, we analyse the evolution of insolvency cases between 2009 and 2011, in order to see which the most precarious sectors are.

Table 1 shows the evolution of insolvencies number between 2009 and 2011, characterized by the activity sector.

As we can see, the construction sector is the most affected by insolvencies, increasing from 916 in 2009 to 1,401 in 2011, representing a raise of about 53\%, well above the overall increase of $37 \%$. In this context, we focused our study in the construction industry.

The sample consists of 150 failed and 150 operating construction firms. The first group includes firms that were considered insolvent between 2010 and 2011. The financial and economic data were collected from the SABI database of Bureau Van Dijk, considering the following filters: the firm must be Portuguese, belong to the construction sector, be a legally public or private held company, have a maximum of 250 employees and must have information available from 2005 to 2010. With these criteria 150 small and medium sized companies were obtained.

The group of operating firms must be in activity at the data collection date. A sample of 150 "healthy" companies was taken keeping the same criteria as above mentioned.

\section{Empirical Results}

Table 2 reports the Pearson correlations among the independent variables for all the firms (Panel A), the insolvent firms (Panel B) and the "healthy" firms (Panel C). For reasons of simplicity, only the results for the year prior to the insolvency are shown.

Concerning the global sample (Panel A), we can see that the highest values for correlations are between CFA and ROA (positive), between ROA and Debt (negative) and between CFA and Debt (negative). When observing the insolvent firms (Panel B), it is noticed that highest correlations are between CFA and ROA (positive) and between CFA and ATR (negative). Finally, in relation to operating firms (Panel C), the highest value for the Pearson correlation is between CFA and 
WCR. Globally, it does not appear to be sufficiently large to cause concern about multicollinearity problems.

Table 3 presents the variables descriptive statistics for the year prior to insolvency regarding the insolvent companies (Panel A) and the operating companies (Panel B).

As expected, the group of insolvent firms presents lower levels of liquidity and profitability, and higher levels of indebtedness, reflecting its financial distress. Furthermore, the cash-flow to total assets is negative in insolvent firms, and positive in operating firms.

We estimate the LPM, the Logit and the Probit models. Table 4 presents the results for the three models in the year prior to insolvency, considering first all previously mentioned ratios (Panel A) and later the ratios considered significant to predict insolvency (Panel B).

It is important to emphasize that, according the F-statistic in LPM and the LRstatistic in Logit and Probit models, all the models are statistically significant at $1 \%$ level, explaining the insolvency phenomenon. This result is important because, otherwise, the models would be inappropriate for the study of forecasting insolvency.

According the LPM results (Panel A), with the exceptions of the return on equity and the current ratio, all the other variables are statistically significant, being appropriate for the bankruptcy prediction.

According to the LPM results on Panel B, where only the significant variables of LPM initial model (Panel A) were considered, the results can be expressed as follows:

$$
\text { prob }_{i}=0.38-1.13 \text { CFA + 0.12 Debt }+0.49 \text { ROA }-0.16 \text { ATR + 0.22 WCR - 0.0002 NSM }
$$

This is the expression of LPM for the previous year before insolvency. It can be concluded that $61.54 \%$ of variations of endogenous variable are explained by the model, according to the R-squared.

However, although we expect a positive value only for the coefficient of indebtedness, the ROA and the WCR show also positive values, meaning that, as these ratios increase, the likelihood of the company being insolvent is higher.

Regarding the Logit and Probit models estimates (Panel A), the cash-flow to total assets and the asset turnover ratio are statistically significant and have the expected sign. In addition, for the Probit model, the return on assets is also significant. 
The Panel B shows the estimated coefficients considered relevant in the previous Panel. In the Probit model, the return on assets ratio is relevant but the sign is contrary to the expected one.

The Logit model's regression can be expressed in the following way:

$$
\operatorname{Prob}_{\mathrm{i}}=\frac{1}{1+\mathrm{e}^{-(4.57-29.79 \mathrm{CFA}-1.51 \mathrm{ATR})}}
$$

The estimative of Probit in the previous year can be described by the expression:

$$
\operatorname{prob}_{\mathrm{i}}=\Phi(2.89-19.16 \mathrm{CFA}+7.01 \mathrm{ROA}-1.09 \mathrm{ATR})
$$

According to the Probit model results, it can be stated that when cash-flow to total assets and assets turnover ratio are higher, the probability of a firm become insolvent is lower. Nevertheless, the fact of return on assets being directly related with insolvency probability is an interesting result. In what concerns the return on assets, our results are consistent with the ones of Barros (2008). However, we find a negative sign in the turnover assets ratio, and Barros (2008) found a positive sign.

Comparing through the McFadden's R-squared, the Probit model is more enhanced than the Logit, because the Probit value is higher. However, we cannot compare directly the R-squared of those models with the one of the LPM model.

Table 5 shows the results for the second year previous of insolvency, considering all the ratios (Panel A) and only those considered significant to predict insolvency (Panel B).

Compared with Table 4 in the LPM, there is a reduction in the explanatory power of the model for the second year before the insolvency, decreasing the Rsquared from $61.54 \%$ to $60.37 \%$. It can be seen that all variables are statistically significant except the profitability on net sales ratio that becomes insignificant in relation to the previous year before insolvency (Panel A).

The expression of the probability of insolvency when reducing the number of independent variables (Panel B) can be expressed as:

prob $_{\mathrm{i}}=0.60-1.28 \mathrm{CFA}+0.18 \mathrm{Debt}+0.73 \mathrm{ROA}-0.097 \mathrm{ATR}+0.34 \mathrm{WCR}-0.0009 \mathrm{ROE}$

As we can see, all the coefficients have the expected signal, with the exception of the ROA. 
Regarding the Logit and the Probit models (Panel B), all the variables are significant. However, the WCR and the profitability on net sales ratio present a positive sign when they are expected to be negative.

The results indicate that the higher the values on ROA, WCR and debt ratios, the higher the probability of a firm becoming insolvent in two years before the insolvency. In addition, when the cash-flow ratio increases, the probability of insolvency decreases.

The expression of the Logit model for the second year previous the insolvency is the following:

$$
\begin{aligned}
& \operatorname{prob}_{\mathrm{i}}=\frac{1}{1+\mathrm{e}^{-(-0.21-23.69 \mathrm{CFA}+3.07 \text { Debt }+12.78 \mathrm{ROA}+2.09 \mathrm{WCR})}} \\
& \operatorname{prob}_{\mathrm{i}}=\Phi(-0.08-13.52 \mathrm{CFA}+1.75 \mathrm{Debt}+7.95 \mathrm{ROA}+1.13 \mathrm{WCR})
\end{aligned}
$$

The Probit model can be expressed as follows:

The explanatory capacity of the two models decreases slightly from the first to the second year, according to the McFadden's R-Squared. It decreases from 0.76 to 0.75 in both models. For this year, the Probit model is better than the Logit model.

For the third year prior to the bankruptcy, the LPM results in the following expression ${ }^{1}$ :

$$
\text { prob }_{i}=0.29-1.55 \mathrm{CFA}+0.202 \mathrm{Debt}+0.91 \mathrm{ROA}-0.1 \mathrm{ATR}+0.57 \mathrm{WCR}+0.005 \mathrm{NSM}
$$

Concerning the significant ratios, the turnover on assets ratio, the debt ratio and the cash-flow to total assets present the expected sign. Nevertheless, the profitability indicators sign remain positive, opposite to the expected negative. The R-squared of that expression is $62.17 \%$. This percentage increased comparing with the last years.

The Logit model is the following:

$$
\operatorname{prob}_{\mathrm{i}}=\frac{1}{1+\mathrm{e}^{-(-0.75-22.42 \mathrm{CFA}+4.4 \text { Debt }-1.19 \mathrm{ROA}+6.19 \mathrm{WCR})}}
$$

\footnotetext{
${ }^{1}$ For reasons of simplicity, we do not include the following tables, but they are available upon request to the authors.
} 
The Probit model can be expressed as:

$$
\operatorname{prob}_{\mathrm{i}}=\Phi(-0.45-12.44 \mathrm{CFA}+2.44 \mathrm{Debt}-0.7 \mathrm{ROA}+3.7 \mathrm{WCR})
$$

From the obtained results, when cash-flow and the ROA increase, the probability of a firm to become insolvent decreases. On the other hand, when WCR and debt ratio increase, the probability is higher. With the exception of the WCR, all the other coefficients are coherent with the expected sign. Once again, the Probit model is better, presenting a McFadden R-squared of 0.75 .

The estimations for the fourth year previous of insolvency results in the following expressions for the LPM model (11), the Probit model (12) and the Logit model (13):

$$
\operatorname{prob}_{\mathrm{i}}=0.56-1.54 \mathrm{CFA}+0.16 \mathrm{Debt}+0.59 \mathrm{ROA}+0.39 \mathrm{WCR}+0.01 \mathrm{NSM}
$$

In this year the capacity to explain the probability of bankruptcy with the LPM model decreases approximately $60 \%$. According to our expectations, the cash-flow to total assets is negative and the debt ratio is positive, suggesting that firms with higher ratios of cash-flow to total assets present lower probability of bankruptcy and that higher level of indebtedness results in higher probability to become insolvent. Once again, the profitability ratios have a positive impact in insolvency probability.

$$
\begin{gathered}
\operatorname{prob}_{\mathrm{i}}=\frac{1}{1+\mathrm{e}^{-(3.2-22.4 \mathrm{CFA})}} \\
\operatorname{prob}_{\mathrm{i}}=\Phi(1.84-12.9 \mathrm{CFA})
\end{gathered}
$$

In expression (13), the sign of the only relevant ratio is negative, according to our expectation. The fact that many ratios are irrelevant led to the conclusion that by the fourth year before insolvency it is hard to demonstrate if a firm will become insolvent or not in a foreseeable future.

Finally, we present the results for the estimations for the fifth year previous the insolvency. It was expected that the model presents a lower capacity of explaining the bankruptcy probability given the time distance to the phenomenon. 
According to the model results, we can express the LPM model as follows:

$\operatorname{prob}_{\mathrm{i}}=0.46-1.47 \mathrm{CFA}+0.22 \mathrm{Debt}+0.0015 \mathrm{CR}+0.9 \mathrm{ROA}+0.48 \mathrm{ATR}+0.48 \mathrm{WCR}-0.056 \mathrm{ROE}$

There are 7 determinants of bankruptcy and the explaining power of the model is $61.2 \%$.

The expression of the Logit model can be expressed by:

$$
\text { prob }_{i}=\frac{1}{1+\mathrm{e}^{-(-0.1-14.36 \mathrm{CFA}+2.33 \mathrm{Debt}+2.22 \mathrm{WCR})}}
$$

According to these two models, the results show that the likelihood to become insolvent decreases with the cash-flow to total assets ratio, and increases with the indebtedness and WCR.

The Probit model can be shown by the following expression:

$$
\text { prob }_{\mathrm{i}}=\Phi(-0.75-7.9 \mathrm{CFA}+2 \mathrm{Debt}+3.78 \mathrm{ROA}+1.75 \mathrm{WCR})
$$

According to (16), the probability of a firm to become insolvent increases with debt, ROA and WCR, and decreases with CFA.

From the fourth to the fifth year before insolvency, the McFadden's R-Squared decreases in both models, from 0.69 to 0,64 in the Logit model and from 0.70 to 0,64 in the Probit model.

Summarising the obtained results, the Logit and the Probit models loose adjustment quality as the year considered moves away from the year in which the companies were declared insolvent, which can be seen in the McFadden R-squared that decreases when we move away from the insolvency year. In general, the Probit model presents more robust results than the Logit $\operatorname{model}^{2}$.

The current ratio is not important to the prediction of insolvency, since it is not statistically significant in all years, and for all models, with the exception of the MPL (and only in the fifth year prior to insolvency).

\footnotetext{
${ }^{2}$ Although the McFadden R-square is a measure of quality fitting, it cannot be directly compared with the R-squared of MPL.
} 
The cash-flow to total assets ratio is negative and statistically significant in all models, as well as in all the periods, suggesting that the likelihood of a firm to become insolvent decreases with the cash-flow on total assets ratio.

The results show that the probability to bankruptcy increases with the indebtedness of the companies. This evidence is consistent with the results of Ohlson (1980), Zavgren (1985), Barros (2008) and Ribeiro (2011), which generally concluded that the debt ratio has a positive impact on the insolvency prediction. Despite the sign is always positive for the Logit and Probit models, in two of the years it does not show statistically significant values. A possible explanation for this evidence is based on the evidence that both operating and insolvent firms present high degrees of indebtedness in these years.

The ROA and the WCR have been inconsistent with our expectations. Although we expect a negative sign, the results show a positive coefficient. However, the WCR sign is consistent with the results of Altman (1968).

The ROA ratio presents the expected sign in the Logit and the Probit models, but only for the third year before the insolvency. The ROE and the profitability on net sales do not appear to be good predictors to explain the insolvency phenomenon, which is in line with the results of Zavgren (1985). Particularly, the profitability on net sales has only statistical significance in the first, third and fourth year prior to the insolvency in the LPM, and the sign is negative in the first year and positive in the other two periods, which suggests that the analysis of the capacity of generating a net margin on sales is not the main factor to explain the insolvency phenomenon. Although there is consistency with the negative sign of the ROE, this is only significant in the linear probability model in the second and fifth year prior of insolvency.

The turnover asset ratio appears to be a good predictor of insolvency in the three years prior to insolvency in LPM, but only in the first year prior to insolvency in the case of the Probit and the Logit models. Its sign is negative, suggesting that the higher the ratio of turnover asset, the less the probability of a company to become insolvent. This variable is not statistically significant after the third year prior to the bankruptcy, which might be explained by the similar ROA values in the "healthy" and "non-healthy" firms.

In sum, the ratio that has more capacity to predict bankruptcy over the different periods in the Portuguese construction industry is the ratio of cash-flow to total assets, which is consistent with the results of Beaver (1966).

Although we compare our results with previous studies, we must be cautious because the results are dependent on the period of analysis, the industry considered and the economic and social environment. 


\section{Conclusion}

In the actual context of recession, companies are facing financial increasing difficulties, being relevant the analysis of the probability of bankruptcy. In this context, we run different models of insolvency, considering a sample of Portuguese firms in the construction industry, which had suffered with the global crisis context.

The LPM, the Logit and the Probit models were adopted.

Globally, we find evidence that the variables that can explain the phenomenon of insolvency are the liquidity, leverage, profitability and activity ratios. Overall, the conditional probability models, the Logit and the Probit, exhibit a decrease in the explanatory power over the period in which they move away from the insolvency year.

When comparing the Logit and the Probit models, the results shows that, globally, the Probit is the best model to explain the phenomenon of insolvency, telling that the sample of companies are homogeneous.

The results achieved with the econometric models suggest that there is a relationship between the economic and financial indicators and the probability that a company presents financial difficulties. However, not all the ratios have the same predictive capacity. The profitability ratios do not appear to be good predictors of insolvency, as also concluded by Zavgren (1985). In addition, the results show a positive relationship between the debt ratio and the probability of a firm becoming insolvent, which is in accordance with several previous studies (Ohlson, 1980; Zavgren, 1985; Barros, 2008; Ribeiro, 2011).

We conclude that the ratio that can best catch the phenomenon of insolvency in the Portuguese construction industry is the cash-flow to total assets ratio. Beaver (1966) found also a significant relationship between this ratio and the probability of insolvency.

The conducted research can help in the determination of some warning signs of insolvency, as well as in the relative positioning of each company in terms of insolvency risk. However, we must be aware that the global crisis might influence the findings. 


\section{References:}

Agarwal, V., \& Taffler, R., (2008), "Comparing the performance of market-based and accounting-based bankruptcy prediction models", Journal of Banking \& Finance, 32, pp. 1541-1551.

Altman, E., (1968), "Financial Ratios, Discriminant Analysis and the Prediction of Corporate Bankruptcy”, The Journal of Finance, 23 (4), pp. 589-609.

Altman, E., Haldeman, R., \& Narayanan, P., (1977), "Zeta analysis: A new model to identify bankruptcy risk of corporations", Journal of Banking and Finance, 1, pp. 29-54.

Barros, G., (2008), "Modelos de previsão da falência de Empresas: Aplicação Empírica ao Caso das Pequenas e Médias Empresas Portuguesas", Master Dissertation, ISCTE, Instituto Universitário de Lisboa.

Beaver, W., (1966), "Financial Ratios as Predictors of Failure", Empirical Research in Accounting, selected studies, in supplement to the Journal of Accounting Research, pp. 71-111.

Blum, M. (1974), "Failing Company Discriminant Analysis", Journal of Accounting Research, Spring, pp. 1-25.

COFACE - Serviços Portugal (2012), Estudo anual de insolvências, créditos vencidos e constituições de empresas Portugal 2011.

Correa, A., Acosta, M., \& González, A. L., (2003), "La insolvencia empresarial: un análisis empírico para la pequeña y mediana empresa", Spanish Accounting Review, 6 (12), pp. 47-79.

Edmister, R. (1972), “An Empirical Test of Financial Ratio Analysis for Small Business Failure Prediction”, The Journal of Financial and Quantitative Analysis, 7 (2), pp. 1477 1493.

Frydman, H., Altman, E., \& Kao, D., (1985), "Introducing Recursive Partitioning for Financial Classification: The Case of Financial Distress", The Journal of Finance, 40 (1), pp. 269-291.

Lacerda, A., \& Moro, A., (2008), Analysis of the predictors of default for Portuguese firms. Working Paper 22, Banco de Portugal, Retrieved: 15 March 2013, http:/www.diwecon.de/de/downloads/Moro\%20BdP_2008-22.pdf.

Laitinen, T., \& Kankaanpää, M., (1999), "Comparative analysis of failure prediction methods: the Finnish case", The European Accounting Review, 8 (1), pp. 67-92.

Leal, C., \& Machado-Santos, C., (2007), "Insolvency prediction in the Portuguese textile industry", European Journal of Finance and Banking Research, 1 (1), pp. 16-28.

McFadden, D., (1974), Condicional Logit Analysis of Qualitative Choice Analysis. New York: Academic Press.

Ohlson, J., (1980), "Financial Ratios and the Probabilistic Prediction of Bankruptcy", Journal of Accounting Research, 18 (1), pp. 109-131.

Ribeiro, S., (2011), "Modelos de Previsão de Incumprimento Fiscal Através de Informação Financeira: Estudo das Empresas de Mobiliário de Madeira” Master Dissertation, Faculdade de Economia da Universidade do Porto. 
Ugurlu, M., \& Aksoy, H., (2006), "Predicting Corporate financial distress in an emerging market: the case of Turkey", Cross Cultural Management: An International Journal, 13 (4), pp. 277-295.

Voulgaris, F., Doumpos, M., \& Zopounidis, C., (2000), "On the Evaluation of Greek Industrial SMEs': Performance via Multicriteria Analysis of Financial Ratios”, Small Business Economics, 15, pp. 127-136.

Wooldridge, J., (2009) Introductory Econometrics. South-Western: Cengage Learning.

Zavgren, C., (1985), “Assessing the vulnerability to failure of American Industrial Firms: A Logistic Analysis”, Journal of Business \& Accounting, 12 (1), pp. 19-45.

Zmijewski, M., (1984), "Methodological Issues Related to the Estimation of Financial Distress Prediction Models", Journal of Accounting Research, 22 Supplement, pp. 59-82. 
Table 1:Evolution of insolvency in Portugal between 2009 and 2011, by activity sector

\begin{tabular}{lcccccc}
\hline & \multicolumn{3}{c}{ Number } & \multicolumn{3}{c}{$\%$} \\
\cline { 2 - 7 } Sector & $\mathbf{2 0 0 9}$ & $\mathbf{2 0 1 0}$ & $\mathbf{2 0 1 1}$ & $\mathbf{2 0 0 9}$ & $\mathbf{2 0 1 0}$ & $\mathbf{2 0 1 1}$ \\
\hline Agriculture & 120 & 146 & 269 & $2.7 \%$ & $2.8 \%$ & $4.4 \%$ \\
Retail Commerce & 577 & 648 & 888 & $13.0 \%$ & $12.6 \%$ & $14.6 \%$ \\
Vehicles Commerce & 139 & 167 & 210 & $3.1 \%$ & $3.2 \%$ & $3.5 \%$ \\
Gross Commerce & 680 & 745 & 858 & $15.3 \%$ & $14.5 \%$ & $14.1 \%$ \\
Construction & 916 & 1,180 & 1,401 & $20.6 \%$ & $22.9 \%$ & $23.1 \%$ \\
Electricity, gas and water & 2 & 3 & 5 & $0.0 \%$ & $0.1 \%$ & $0.1 \%$ \\
Hospitality Industry & 173 & 230 & 349 & $3.9 \%$ & $4.5 \%$ & $5.7 \%$ \\
Clothing Industry & 498 & 519 & 511 & $11.2 \%$ & $10.1 \%$ & $8.4 \%$ \\
Manufacturing & 555 & 631 & 689 & $12.5 \%$ & $12.3 \%$ & $11.3 \%$ \\
Services & 395 & 491 & 628 & $8.9 \%$ & $9.5 \%$ & $10.3 \%$ \\
Transports & 207 & 201 & 253 & $4.7 \%$ & $3.9 \%$ & $4.2 \%$ \\
Others & 188 & 183 & 16 & $4.2 \%$ & $3.6 \%$ & $0.3 \%$ \\
\hline Total & $\mathbf{4 , 4 5 0}$ & $\mathbf{5 , 1 4 4}$ & $\mathbf{6 , 0 7 7}$ & $\mathbf{1 0 0 \%}$ & $\mathbf{1 0 0 \%}$ & $\mathbf{1 0 0 \%}$ \\
\hline
\end{tabular}

Source: COFACE (2012) 
Table 2: Correlation matrix

\begin{tabular}{|c|c|c|c|c|c|c|c|c|}
\hline \multicolumn{9}{|c|}{ Panel A: All Companies } \\
\hline & CFA & Debt & $\mathrm{CR}$ & ROA & ATR & WCR & NSM & ROE \\
\hline CFA & 1 & -0.5881 & 0.2077 & 0.7054 & -0.3708 & 0.5411 & 0.029 & 0.005 \\
\hline Debt & & 1 & -0.1354 & -0.6146 & 0.3669 & -0.5232 & 0.0718 & 0.0228 \\
\hline $\mathrm{CR}$ & & & 1 & 0.0448 & -0.1108 & 0.1842 & 0.0006 & -0.0044 \\
\hline ROA & & & & 1 & -0.5458 & 0.3262 & -0.0041 & 0.0081 \\
\hline ATR & & & & & 1 & -0.3644 & 0.0746 & -0.0229 \\
\hline WCR & & & & & & 1 & 0.0254 & -0.0621 \\
\hline NSM & & & & & & & 1 & 0.0011 \\
\hline $\mathrm{ROE}$ & & & & & & & & 1 \\
\hline \multicolumn{9}{|c|}{ Panel B: Insolvent Companies } \\
\hline & CFA & Debt & $\mathrm{CR}$ & ROA & ATR & WCR & NSM & ROE \\
\hline CFA & 1 & -0.6782 & 0.2827 & 0.9958 & -0.7202 & 0.3668 & 0.0218 & 0.0091 \\
\hline Debt & & 1 & -0.4736 & -0.6757 & 0.6159 & -0.6122 & 0.1115 & 0.0245 \\
\hline $\mathrm{CR}$ & & & 1 & 0.2956 & -0.1746 & 0.4849 & -0.2284 & -0.0887 \\
\hline ROA & & & & 1 & -0.7374 & 0.3731 & -0.0259 & -0.0018 \\
\hline ATR & & & & & 1 & -0.4372 & 0.0859 & -0.0293 \\
\hline WCR & & & & & & 1 & 0.0101 & -0.0729 \\
\hline NSM & & & & & & & 1 & 0.0008 \\
\hline ROE & & & & & & & & 1 \\
\hline \multicolumn{9}{|c|}{ Panel C: Operating Companies } \\
\hline & CFA & Debt & $\mathrm{CR}$ & ROA & ATR & WCR & NSM & ROE \\
\hline CFA & 1 & 0.0449 & 0.2663 & -0.1561 & -0.3114 & 0.9118 & 0.0027 & -0.1717 \\
\hline Debt & & 1 & -0.1986 & 0.025 & -0.1101 & 0.023 & -0.1492 & 0.2165 \\
\hline $\mathrm{CR}$ & & & 1 & -0.0087 & -0.1969 & 0.2768 & 0.0549 & -0.0349 \\
\hline ROA & & & & 1 & -0.2203 & -0.1112 & 0.1325 & 0.7064 \\
\hline ATR & & & & & 1 & -0.3229 & 0.0513 & 0.0043 \\
\hline WCR & & & & & & 1 & 0.1077 & -0.1159 \\
\hline NSM & & & & & & & 1 & 0.0927 \\
\hline ROE & & & & & & & & 1 \\
\hline
\end{tabular}


Table 3: Descriptive statistics

\begin{tabular}{ccccccccc}
\hline \multicolumn{7}{c}{ Panel A: Insolvent Companies } \\
\hline CFA & Debt & CR & ROA & ATR & WCR & NSM & ROE \\
\hline Median & 0.0021 & 0.8949 & 1.1046 & -0.0177 & 0.7598 & 0.3754 & -0.0288 & 0.0388 \\
Maximum & 0.3151 & 5.8703 & 5.8566 & 0.3102 & 6.7862 & 0.9183 & 0.5744 & 69.9892 \\
Minimum & -2.3714 & 0.1144 & 0.0503 & -2.8333 & 0.0000 & -2.0687 & -8.3940 & 8.0212 \\
Std. Dev. & 0.3765 & 0.7512 & 0.8343 & 0.3881 & 0.9640 & 0.4161 & 1.1519 & 8.0213 \\
\hline \multirow{2}{*}{ Mean } & & \multicolumn{2}{c}{ Panel B: Operating Companies } & & \\
\hline \multirow{2}{*}{ Mean } & 0.4506 & 0.6902 & 3 & 0.0145 & 1.0821 & 0.4775 & -0.0706 & 0.1082 \\
Median & 0.4278 & 0.7307 & 1.4474 & 0.021 & 1.0442 & 0.4363 & 0.0177 & 0.0729 \\
Maximum & 0.9998 & 2.9914 & 21.2118 & 0.3167 & 5.2819 & 0.9998 & 14.2016 & 1.3253 \\
Minimum & 0.0312 & 0.0055 & 0.3343 & -1.4674 & 0.0005 & 0.0487 & -27.8089 & -1.8669 \\
Std. Dev. & 0.2597 & 0.3155 & 18.3446 & 0.1552 & 0.7230 & 0.2447 & 2.4689 & 0.2808 \\
\hline
\end{tabular}


Table 4: Estimation results for the first year before insolvency

\begin{tabular}{|c|c|c|c|c|c|c|}
\hline \multicolumn{7}{|c|}{ Panel A: All the independent variables } \\
\hline & \multicolumn{2}{|c|}{ MPL (OLS) } & \multicolumn{2}{|c|}{ Logit (MLE) } & \multicolumn{2}{|c|}{ Probit (MLE) } \\
\hline & Coef. & Prob. & Coef. & Prob. & Coef. & Prob. \\
\hline Constant & 0.6693 & 0.0000 & 3.6156 & 0.0417 & 2.1307 & 0.0378 \\
\hline CFA & -1.1458 & 0.0000 & -33.5934 & 0.0000 & -18.5666 & 0.0000 \\
\hline Debt & 0.1293 & 0.0394 & 1.7350 & 0.3034 & 0.8679 & 0.3639 \\
\hline $\mathrm{CR}$ & 0.0006 & 0.3422 & -1.1426 & 0.6276 & -0.0881 & 0.5939 \\
\hline ROA & 0.5076 & 0.0388 & 11.4067 & 0.1098 & 6.8123 & 0.0689 \\
\hline ATR & -0.1635 & 0.0000 & -2.1781 & 0.0047 & -1.2260 & 0.0029 \\
\hline WCR & 0.2422 & 0.0017 & 1.9270 & 0.1786 & 1.0357 & 0.1852 \\
\hline NSM & -0.0002 & 0.0000 & -0.1149 & 0.5664 & -0.0629 & 0.5428 \\
\hline ROE & 0.0000 & 0.9976 & 0.0267 & 0.6174 & 0.0152 & 0.5822 \\
\hline McFadden R-squared & & & 0.8174 & & 0.8178 & \\
\hline LR statistic & & & 320.6685 & & 320.8448 & \\
\hline Prob (LR statistic) & & & 0.0000 & & 0.0000 & \\
\hline R-squared & 0.6154 & & & & & \\
\hline F statistic & 74.1343 & & & & & \\
\hline Prob (F statistic) & 0.0000 & & & & & \\
\hline \multicolumn{7}{|c|}{ Panel B: The significant independent variables } \\
\hline Constant & 0.3825 & 0.0000 & 4.5722 & 0.0000 & 2.8865 & 0.0000 \\
\hline CFA & -1.1304 & 0.0000 & -29.7859 & 0.0000 & -19.1577 & 0.0000 \\
\hline Debt & 0.1186 & 0.0457 & & & & \\
\hline ROA & 0.4923 & 0.0337 & & & 7.0087 & 0.0383 \\
\hline ATR & -0.1629 & 0.0003 & -1.5103 & 0.0204 & -1.0883 & 0.0032 \\
\hline WCR & 0.2241 & 0.0023 & & & & \\
\hline ROE & -0.0002 & 0.0001 & & & & \\
\hline McFadden R-squared & & & 0.8040 & & 0.8131 & \\
\hline LR statistic & & & 326.4513 & & 330.1408 & \\
\hline Prob (LR statistic) & & & 0.0000 & & 0.0000 & \\
\hline R-squared & 0.6154 & & & & & \\
\hline F statistic & 74.1343 & & & & & \\
\hline Prob (F statistic) & 0.0000 & & & & & \\
\hline
\end{tabular}


Table 5: Estimation results for the second year before insolvency

\begin{tabular}{|c|c|c|c|c|c|c|}
\hline \multicolumn{7}{|c|}{ Panel A: All the independent variables } \\
\hline & \multicolumn{2}{|c|}{ MPL (OLS) } & \multicolumn{2}{|c|}{ Logit (MLE) } & \multicolumn{2}{|c|}{ Probit (MLE) } \\
\hline & Coef. & Prob. & Coef. & Prob. & Coef. & Prob. \\
\hline Constant & 0.6025 & 0.0000 & 0.5342 & 0.6488 & 0.3018 & 0.6597 \\
\hline CFA & -1.3000 & 0.0000 & -24.8663 & 0.0000 & -13.9133 & 0.0000 \\
\hline Debt & 0.1760 & 0.0169 & 3.0467 & 0.0231 & 1.7375 & 0.0230 \\
\hline $\mathrm{CR}$ & 0.0004 & 0.0709 & 0.0239 & 0.0511 & 0.0131 & 0.0545 \\
\hline ROA & 0.7614 & 0.0012 & 13.8680 & 0.0129 & 8.5841 & 0.0047 \\
\hline ATR & -0.0914 & 0.0106 & -0.5241 & 0.1949 & -0.2849 & 0.1992 \\
\hline WCR & 0.3394 & 0.0000 & 1.9999 & 0.0642 & 1.0809 & 0.0725 \\
\hline NSM & -0.0109 & 0.3780 & -0.6027 & 0.0239 & -0.3345 & 0.0246 \\
\hline ROE & -0.0009 & 0.0004 & -0.0233 & 0.9363 & -0.0200 & 0.9574 \\
\hline McFadden R-squared & & & 0.7569 & & 0.7586 & \\
\hline LR statistic & & & 310.5645 & & 311.2592 & \\
\hline Prob (LR statistic) & & & 0.0000 & & 0.0000 & \\
\hline R-squared & 0.6055 & & & & & \\
\hline F statistic & 55.0613 & & & & & \\
\hline Prob (F statistic) & 0.0000 & & & & & \\
\hline \multicolumn{7}{|c|}{ Panel B: The significant independent variables } \\
\hline Constant & 0.6049 & 0.0000 & -0.2093 & 0.8478 & -0.0814 & 0.898 \\
\hline CFA & -1.2797 & 0.0000 & -23.6852 & 0.0000 & -13.52 & 0.0000 \\
\hline Debt & 0.1777 & 0.0164 & 3.0731 & 0.0143 & 1.748 & 0.0142 \\
\hline ROA & 0.7331 & 0.0008 & 12.7804 & 0.0292 & 7.9514 & 0.0057 \\
\hline ATR & -0.0973 & 0.0055 & & & & \\
\hline WCR & 0.3448 & 0 & 2.0906 & 0.0457 & 1.1305 & 0.0496 \\
\hline ROE & -0.0009 & 0.0004 & & & & \\
\hline McFadden R-squared & & & 0.7467 & & 0.7493 & \\
\hline LR statistic & & & 307.4007 & & 308.4770 & \\
\hline Prob (LR statistic) & & & 0.0000 & & 0.0000 & \\
\hline R-squared & 0.6037 & & & & & \\
\hline F statistic & 73.6284 & & & & & \\
\hline Prob (F statistic) & 0.0000 & & & & & \\
\hline
\end{tabular}

